\title{
Striving for liminality: Eating disorders and social suffering
}

\section{Citation:}

Eli, K. (forthcoming). Striving for liminality: Eating disorders and social suffering.

Transcultural Psychiatry.

\section{Publisher's version:}

TBA

\section{Abstract}

In this article, I argue that eating disorders constitute a form of social suffering, in which sufferers embody liminality as a response to, and a reflection of, oppressive sociality, structural violence, and institutional constraints. Based on the illness narratives of people with anorexia nervosa, bulimia nervosa, and their subclinical variants in Israel, the analysis draws the experiential, the social, and the structural into critical focus. These narratives, which delineate lived experiences of self-starving, bingeing, and purging, and the attendant viscerality of hunger, fullness, and emptiness, reveal how participants developed an embodied drawing inward and away, being at once within and without society for extended periods of time, through eating disordered practices. This liminal positioning, I argue, was a mode through which participants cultivated alternative (if temporary) personal spaces, negotiated identities, and anesthetized pain: processes many deemed essential to survival. Embedding the participants' narratives of eating disordered experiences within familial, societal, and political-economic forces that shaped their individual lives, I examine the participants' striving for liminality as at once intimately embodied and structurally mapped. The analysis suggests that policy initiatives for eating disorder prevention must address the social suffering that eating disorders manifest: suffering caused by structures and institutions that reinforce social inequality, violence, and injustice.

Keywords: eating disorders; illness narratives; Israel; liminality; medical anthropology; social suffering 


\section{Introduction}

All my plans failed. Suddenly, I didn't graduate from high school with everyone, because in twelfth grade, I was never in school, I was with my mother all around the country in every possible hospital, in every possible diagnostic exam. (...) And I didn't go to the military, and suddenly I couldn't go to study (in university) because I couldn't leave my mother, because for a long long long long time they didn't want to fund a home aid for us. I was - I fought so hard for it, and I grew distant from myself and from my purpose. And actually, at the point where I lost myself and I lost all purpose in life, I found myself - for myself, at least, the simplest goal there is, thin. That's it. That. To be thin. To be different. Because there - that was the thought, that I can't fail there. Nothing external can affect me. (Aline)

When I met Aline in March 2006, she was 20 years old and living in difficult circumstances. Having been diagnosed with an eating disorder, Aline nonetheless continued to function as a carer for her disabled single mother - a role she held since secondary school. Amidst these difficulties, she said, her eating disorder was 'something that walks along with me, in case I need comfort'. While her stated purpose '[t]o be thin' was aligned, on one level, with the desire to be awarded the 'title' of anorexia - a desire common to people with eating disorders (Eli, 2014a; Warin, 2010) - it also enfolded a process of developing a new being-in-theworld, marked by the embodied practice of self-starvation, exercise, and occasional binge eating and purging. When Aline reached for the 'comfort' of anorexia (which, she said, she imagined carrying in her 'pocket'), she was not reaching for thinness, but rather, for the practice through which she cultivated it (cf. Lavis, 2013).

Aline's reliance on eating disordered practice for emotional 'comfort' would not be surprising to clinicians working in the eating disorders field. Eating disordered practices, including dietary restriction, binge eating, and purging, have been discussed in the clinical literature as means of coping with negative affect, including anxiety and dysphoric mood (Fairburn et al., 2003; Kaye et al., 2009). Indeed, Aline said that her therapist kept urging her to acquire 'healthy tools' with which to replace anorexia. Yet Aline kept to her eating disordered toolkit, paradoxically describing the disorder that endangered her as the shield that made her invulnerable. This was because, for Aline, as for the other participants who took part in my study, eating disorder was more than a means of coping with negative affect: it 
offered a mode of becoming 'different', of disconnecting from painful life circumstances, of setting oneself apart.

To examine the co-constitution of coping with negative affect and being set apart from others through eating disorder, I turned to the concept of liminality. Liminality originally designated a phase in rites of passage, wherein the initiand, separated from society, is brought to an extra-communal space where new rules - tests, prohibitions, appearances apply, in preparation for rejoining society as a fully-fledged adult member (Turner, 1967). However, liminality has been applied beyond rites of passage, to describe a range of inbetween states of indefinite temporality and undefined spatiality. In the medical anthropology and sociology literatures, the concept of liminality has been used in critical analyses of patienthood. Analyses have examined how people with chronic illness and chronic pain are made liminal, cast into ambivalent suspension between the worlds of the 'healthy' and the acutely ill. In these analyses, liminality is made through an illness' 'disruption' of a person's life story and sense of self (Bury, 1982; Charmaz, 1983), its enactment of sudden changes in embodiment (Leder, 1990; Little et al., 1998), and the ambiguous, often stigmatized, social positioning to which it leads (Frank, 1995; Jackson, 2005; Murphy et al., 1988). The liminality portrayed by these studies, then, emphasizes the social exclusion imposed on the 'patient' subject by external social strictures. In my study, such forms of liminality also came to the fore: participants were acutely aware that, in being diagnosed with and treated for an eating disorder, they were labelled 'mentally ill', and many had maintained secrecy about their disorders for fear of social stigma and discrimination.

In previous ethnographic analyses of eating disorders, other concepts of liminality have been employed to understand experiences of recovery, food, triggering, and inpatient care. In Garret's analysis (1998), the anorexic subject is the initiand, and anorexia is the liminal phase - a spatial and temporal inversion and introversion, where the person embarks on a ritual journey away from society and towards the self, with recovery as the ultimate goal. Moving away from a rite-of-passage reading of liminality in eating disorders, Warin's analysis of anorexic classifications of foods (2003) describes fat as a liminal substance, transgressing the boundary between liquid and solid, and hence abject. Other forms of boundary-crossing appear in Lavis' (2011) work, where liminality reflects the ambiguous nature of pro-ana 'triggering' textual and visual materials, the ambivalent position of vomiting and exercise as anorexic praxis, and the definition of anorexia itself as a condition that requires constant striving. Turning to clinical care practices, Lester (2007) frames 
treatment for eating disorders as a liminal passage from sickness toward locally specific notions of 'healthy adulthood' (p. 381). And in my own analysis of inpatient experiences, liminality is used to capture the strategic ambivalence with which people with eating disorders situate themselves in inpatient wards, at once 'a part of and apart from' patient communities (Eli, 2014b).

The versatile forms that liminality has taken in research on eating disorders point to the analytic potential of viewing the eating disordered experience through this lens. With 'the eating disordered experience', I refer to the embodied being-in-the-world effected through eating disordered practices, upon its subjective and intersubjective visceral, sensory, perceptual, felt, and cognized aspects. In emphasizing the eating disordered experience, I aim to shift the analytic lens away from eating disorders as individualized, biomedically-defined diagnostic categories, and toward the lived experiences of people with eating disorders as they take shape intersubjectively, thus embedding individual sufferers' conditions within their wider social contexts. Here, the concept of liminality is particularly productive, as it allows us to consider experiences of eating disordered practice in relational interaction between subject and society - a framework that can shed light on how the functional (coping) and the conceptual (being) come to be entangled. In this article, then, I use liminality to conceptualize the participants' modes of being-in-the-world, with particular focus on embodied practice and sensory experience as they implicate not only the person's own experience, but also the dynamics of relatedness they effect (Csordas, 1993).

While embodiment and the senses are central to my conceptualization of liminality, I recognize that micro level experiences of coping, being, and relating are shaped by macro level structures. Aline's narrative, with which I opened this article, exemplifies the linkages between embodied experience and structural vulnerability - vulnerability 'produced... by [a person's] location in a hierarchical social order and its diverse networks of power' (Quesada et al., 2011: 341). Through her eating disorder, Aline strove for both 'comfort' and distinction; this striving, however, could not be separated from the difficult circumstances she faced as the sole carer for her disabled mother, circumstances which were shaped by political-economic forces - namely, the erosion of the welfare state. Aline's situation was not unique: another participant, 22-year-old Danielle, said she had been charged, since the age of 10, with caring for her disabled siblings and severely ill single mother. Like Aline, Danielle developed anorexia as a teenager, could not complete secondary school, and was not drafted to compulsory military service - a crucial exclusion since, in Israel, military service 
designates 'good citizenship' (Sasson-Levy, 2003). Both women's families were socioeconomically disadvantaged; their cases highlight a lacking social care system that forces working class girls into informal carework at home, even at the cost of their education and social mobility (see also Motzafi-Haller, 2012: 166-167).

These examples underscore the need for an ethnographic analysis that links individual experiences of eating disorders with their broader social and structural contexts. The concept of social suffering, as articulated by Kleinman, Das, and Lock (1997), offers a productive framework for this resituating of the eating disordered experience. As defined by Kleinman and Kleinman (1996: 2), suffering is 'a social experience', marked by intrinsic intersubjectivity. Using a flexible framework that captures multiple meanings of the 'social' in suffering, Kleinman and Kleinman (1996) argue that '[c]ollective modes of experience shape individual perceptions and expressions' of suffering (p. 2), and that '[s]ocial interactions enter into an illness experience' (p. 2), such that individual suffering is produced relationally, taking shape within networks of the afflicted and the affected. Beyond kin networks, the sociality of suffering extends to encompass macro-scale processes, institutions, events, and structures that undergird health inequalities and population-level morbidity (Kleinman, Das, \& Lock, 1997). As Kleinman (2010) argues, social suffering implicates 'the medical, the economic, and the political' as 'inseparable' elements in the production of human morbidity, calling into question 'the historical distinction between what is a health problem and what is a social problem' (p. 1519). A social suffering lens, then, can elucidate suffering that develops in response to the harmful impact of 'institutional power' on people's wellbeing and life possibilities (Kleinman, Das, \& Lock, 1997: ix).

In this paper, I use social suffering as a key concept in constructing a critical anthropological analysis of the eating disordered experience. Eating disorders, as anthropologists have shown, are deeply relational, centrally involving the enactment of social boundaries and the renegotiation of kinship (Lester, 1995; Warin, 2010). These relational configurations are entangled with the materiality of suffering that people with eating disorders endure: one cannot separate the impact that self-starvation, binge eating, and purging have on sufferers' kinship networks from the embodied pain these practices inflict. Crucially, in grounding the embodiment of illness within wider relational networks, the concept of social suffering can clarify the intersubjective makings of individual sensory experiences in eating disorders. This concept, moreover, offers a means of elucidating the multiple layers of eating disorders - from the individual to the political - via embodied 
experience. Through a social suffering lens, individual embodied experience emerges as unmasking structural power, such that an eating disorder is understood not simply as the expression of a sufferer's distress, but as the manifestation of the broader social and structural configurations that brought this distress into being (Green, 1998; Kleinman and Kleinman, 1994).

In integrating the concepts of social suffering and liminality, I aim to develop an account of the eating disordered experience that mediates individual embodiment, dynamics of relatedness, and structural possibilities and constraints. Working with an embodiment framework (Csordas, 1993), my analysis attends to the visceral realities of eating disorders as described by participants. Through the lens of liminality, I situate this embodied viscerality within the realms of kinship, social belonging, and the relational development of identity. Interpreting these relational realms through the concept of social suffering, I attend to societal prescriptions of citizenship, inclusion/exclusion, injustice, and inequality, as they emerge in participants' narrated experiences of developing and maintaining eating disorders. With this approach, the analysis addresses multiple layers of the 'social' in eating disorders, from the familial to the institutional, exploring eating disorder as a form of social suffering, wherein sufferers embody liminality as a response to, and a reflection of, oppressive sociality, structural violence, and institutional constraints.

\section{The study}

This article is based on fieldwork interviews I conducted in Israel, as part of a longitudinal, medical anthropology study concerning the subjective experience of eating disorders. The study's first phase (2005-2006) included 36 participants (35 women and one man, aged 17 to 38 years at first interview); I met with 23 of these participants in the second phase of the study (2011). Most participants were recruited through three sources: an informal network developed by the study's key participant, an Israeli eating disorders discussion board, and an outpatient eating disorders clinic. The participants' experiences and diagnoses of eating disorder ranged across the spectrum of anorexia nervosa, bulimia nervosa, and eating disorder not otherwise specified; many had experienced more than one eating disorder, and, at the time of first interview, more than half had an eating disorder for five or more years. All participants, moreover, had experienced 'patienthood', through dedicated eating disorders treatment (inpatient or outpatient), hospitalization in general psychiatric wards, or 
individualized treatment provided by psychiatrists, clinical social workers, psychotherapists, or eating disorders dieticians. The study's sample, recruitment procedures, and interview processes have been described comprehensively elsewhere (Eli, 2014a).

The analysis presented in this paper is largely based on the interviews I conducted in 2005-2006. The interviews' aim was to elicit the participants' illness and recovery narratives. Thus, while the interviews were semi-structured and addressed similar core questions, I adapted them according to each participant's narrative directions. I digitally recorded and transcribed the interviews. Employing a phenomenologically informed analytic lens, I analysed the participants' transcribed narratives for accounts of embodied experiences of eating disordered practice. I then grouped these accounts according to the themes that emerged from the analysis (e.g. 'transcending reality', 'relating and disconnecting'). The thematic sections that follow present discussions of selected, representative case studies; to represent the range of eating disordered practices the participants experienced, each section includes at least one account of self-starvation and one account of binge eating or binge eating and purging. The accounts are situated within each participant's larger narrative, accounting for life history and structural contexts. With this approach, I aim to answer Desjarlais and Throop's (2011) call for anthropological work that weaves together analyses of people's 'lived realities' with critical perspectives on the wider societal forces that shape them (p. 97). While narratives constitute interpretative representations of experience, and do not offer unmediated access to participants' realities, as Moulding (2015) argues, eating disorder narratives evince entanglements of discourse, emotion, and embodied experience, and provide a framework through which links between intersectional positioning, violence, and disordered eating can be discerned.

The study was reviewed and approved by my university's research ethics committee (June 2005 and February 2011), and by an Israeli Kupat Holim (healthcare fund) Helsinki research ethics committee (August 2005). The participants received detailed information sheets and provided written informed consent in both phases of the study. All names used in this articles are pseudonyms; other identifying details have been concealed or altered. 


\section{Transcending reality}

[There's] some sort of screen between you and reality, where you are... you're not really in reality. There's some sort of delay. (Emily)

Emily spoke of this irreality moments after telling me she still starved herself, 'once every few days', in her words. 'It's always the same', she said,

at the beginning it's very difficult and you feel horrible and you're very hungry. And then the morphine begins to work and everything's great. The body secretes morphine - not real morphine, but some substance which is very similar to it. So in anorexia, part of it is also addiction. You become addicted to that drug. (Emily)

When I asked Emily if there was pleasure in this experience, she seemed offended. There was no pleasure in anorexia, she said, only suffering, but the 'morphine' made hunger less acute, less noticeable: a paradoxical positive feedback loop wherein starvation increasingly diminished hunger.

The 'reality' Emily wished to mediate was constructed by institutional grids namely, the military. Emily said she wanted to neutralize her own humanity, which for her was the capacity to hurt others. While she traced her disordered eating and obsessive compulsive disorder to the age of four, she cited her compulsory service in the Israeli Defense Forces (IDF) as having catalyzed her anorexia. Drafted at age 18 to a highly selective combat-supportive unit, Emily was overcome by fear of hurting other people, even if indirectly. At the same time, with military service constructed as 'good citizenship' in Israel (Sasson-Levy, 2003), she felt she had to stay in the IDF: 'In a democratic state, I have duties just like everyone else'. Her request to be reassigned to a non-combat-related role failed, and during basic training, she quickly descended into a haze of self-starvation, her days structured by intensive coursework and hours of self-prescribed exercise. She collapsed within a few months, and was placed on medical leave, which eventually led to a discharge on health grounds; by that time, Emily was severely underweight and acutely ill (see also Eli, 2014c). A decade and two inpatient stays later, Emily continued to live with anorexia. She said that, in her concept of a tolerable existence, hunger - a quintessentially human, animal, desiring sense - had no space. Thus, she mediated her all-too-human existence through starving past the point of hunger. Emily explained that she did not drive because she was constantly high on self-starvation, her vision of the world faded and 'delay[ed]'. And yet she 
moved in this soft-focus reality, studying part-time, dating, and pursuing a career. This liminal existence - through the continuous 'delay' of self-starvation - was a compromise, but one which allowed Emily to participate in an otherwise threatening world.

For many participants, eating disordered practice, with its extremes of dietary restriction, bingeing, and purging, altered reality through carving out private spaces and times. To engage in eating disordered practice was to transform any space, temporarily, into one's own world (Eli, 2014c). Adi, who had bulimia for about a decade, said that binge eating offered all-absorbing, albeit temporally-bound, relief from anxiety and pain; during the binge, she said, 'I think I lost the sense of time, the sense of place'. She described her eating disorder as affording a comforting, almost fetal, existence in a liminal space:

When I was in the disease I felt many times [that I was] behind an aquarium, looking at life and not living it, I'm just looking at it. When I get out of the eating disorder, I would always tell myself, I will live, but now, I still have the privilege of looking at [life] from behind an aquarium and you know, letting it move. (Adi)

Time was suspended within Adi's bulimic 'aquarium', a liminal space that allowed her to observe without partaking. Beyond the aquarium, she said, existed a linear, and uncompromising, march toward successful being:

There's a crowd like that, that invented a method, that invented stages in life... go to primary school, go to high school, serve in the military, get out of the military, start make a trip abroad, get out of the trip abroad, start studying (in university), get out of the studies, marriage, family, ageing, divorcing, it's like everything - is very very structured. (Adi)

Other participants also named the life stages that Adi enumerated, alluding to the highly structured, life-long becoming of 'good' citizens in Israel. For young women, this process of becoming entailed the enactment of collective belonging in secondary school and military or national service, followed by university studies, marriage, and childbearing - with the latter positioned as a crucial part of women's citizenship (Berkovitch, 1997). Constructing women's subjectivity through institutional participation and fertile femininity, these life stages entailed surveillance, both social and biomedical (Eli, 2016). Adi herself strove to succeed within the structures she critiqued, but success eluded her. When she was drafted to the IDF, Adi requested a selective role, and was assigned a low status role instead. This, she 
said, reinforced her extant eating disorder practice, and she binged and purged throughout her military service (Eli, 2014c). Later, with her days still consumed by bulimic practice, she could not complete her undergraduate studies 'on time', shattering her 'wish' of being awarded a degree at a young age.

Adi's positive feedback loop, wherein 'failing' exacerbated bulimic practice, which in turn led to additional 'failing', was rooted not only in the dynamics of eating disorder, but also in social capital. Adi explained she was assigned a low status IDF role because she randomly selected answers in her military aptitude exams; she said she was not aware of the importance of these exams, and thought she would be assigned the role she requested. Then, she was unaware that she could retake the exams to increase her chances of being assigned a selective role. This tale of 'not knowing' and receiving no guidance in navigating the military system reflected Adi's lacking social capital. Adi spoke of lingering shame in her working class family, in her beloved father, whom she described as a 'simple labourer', and whose occupation she hid from her classmates throughout her childhood. As Adi explained, 'it's not just that... I have to feel that I'm very very very clever, but also I have to feel that I come from a good family'. Defining 'good' as 'middle class', Adi was bound to an enduring cycle of shame: 'I always felt that I was starting a few steps behind everyone else', she said. However, within the bulimic aquarium, Adi did not have to catch up to others: she could be submerged in the present.

\section{Relating and disconnecting}

The links between food, eating, and relatedness are familiar territory for anthropology; in psychological analyses of eating disorders, as well, the symbolic power of commensality and of food refusal therein - has been a prominent feature since Lasègue's (1873) defining account of l'anorexie hystérique. But the influence of eating disordered practices on relatedness transcends the symbolics of food, feeding, and commensality. In effecting embodied change - making a new 'being-in-the-world' - eating disordered practice altered the ways in which participants perceived, sensed, and related to others. This embodiment, a drawing inward and away, meant that participants developed a liminal relational world, simultaneously embedded in and removed from bonds of sociality and kinship. After six years of alternating anorexia and bulimia, Dalia explained that the embodiment of hunger allowed her to relate to others from a position of disconnection and strength. 
You're having a relationship with your eating disorder, you're not having a relationship with the world and you don't care about the world.... you don't need food, you're not dependent on anything, and you don't care about pain. My dad used to slap me, no big deal. I came to him - this is what I did to make it stop - I came to him and said, hit me. Why? Because if I had allowed him to hurt me and I would stand [by] and say to him, okay, I don't care, hit me - [it's] emotional disconnection, so he doesn't reach his goal, he doesn't control me. (Dalia)

Dalia offered her account of being beaten by her father as a metaphor. Just as she disconnected from pain and said 'I don't care' to him, so her embodiment of hunger allowed her to disconnect from society, which she found oppressive and painful. Her inner world, she said, was self-sufficient, run by calorie calculations, ritual behaviours, and numbers on scales; there was no space for others in this world, and they could not compromise her needlessness. Dalia traced her desire for needlessness to abuse she experienced in early childhood - abuse that went unaddressed by her teachers and the other adults in her life. These experiences, she said, made her feel that social relations were tainted, that in being victimized repeatedly, she had participated in a corrupt economy of relationality, in connections forged through violence.

For the participants, needlessness was an important feature of altered relationships, but it was not always a reflection of 'conquering' need for food; participants who binged described a social needlessness effected by the utter fullness of food. For example, Lia, whose undefined eating disorder was characterized by binge eating, explained:

I don't feel so connected to this world, so food disconnects even more. And the moment I have the food, I don't need anyone in order to cope with life, I don't need people, I don't need, like, anything. (Lia)

Lia described her social world as fraught with loneliness and tension. From childhood, she said, she was on her own. Although she grew up in an apparently normative, middle class home, Lia said her parents compared her to her more successful siblings, criticized her as 'problematic' and 'unintelligent', and neglected her social and emotional needs to the extent that she had to socialize herself in the minutiae of daily life, which included teaching herself how to eat: 'it was really like, you know, throwing a child into the sea'. Nearly a decade since her eating disorder began, her parents were still unaware that she was ill, and she had to seek treatment on her own. Lia's loneliness persisted into young adulthood, when she found it 
difficult to begin and maintain friendships, and felt like a 'marionette' in the few relationships she did have. In binge eating, her sense of disconnection - her pervasive feeling of not fully belonging to society - was turned into the complete negation of needing people: transforming forced liminality into chosen liminality. This binge-induced denial of need offered protection, albeit temporary, from longings for positive relationality.

\section{Self-Defining}

Eight years after her bout of anorexia, and while recovering from bulimia, Hadas continued to experience hunger as a sensation to long for and revel in. "Hunger is a good sign," she said. "I'm hungry. I'm ok. I'm empty." When I asked her what there was in that emptiness, she responded,

I'm ok. No one can blame me that I ate. Here, I know. I'm empty, I'm ok. Like, my body's empty. I didn't eat. Like, it's simply a proof. And no one can tell me anything, like, no one - I'm not what all of you think, I'm not the child who eats all day. I don't eat and I'm - I'm not like all of you. You eat, like, you're disgusting. I'm different. I'm, like, empty, I'm floating above the surface of the earth.... I'm not contaminated with all sorts of disgusting foods. (Hadas)

The lived experience of emptiness provided Hadas with the 'proof' she continued to seek, proof to counter the unrelenting bullying to which she had been subjected, a decade earlier, as an overweight child. Hadas said that, from childhood to young adulthood, she felt both conspicuous and invisible. In addition to being bullied by her peers, Hadas faced 'weight talk' at home: her adult relatives were vocally preoccupied with their body weights, her father 'waged war' against his own weight gain, and her parents continuously urged her to lose weight. When Hadas developed anorexia as a 15-year-old, her parents complimented her on her weight loss; they did not realize that she was ill and suffering until her weight dropped below 40 kilograms. Against this background, Hadas said that her adolescent self understood fatness as a 'crime against humanity', a 'crime' marked by 'taking others' space, disgusting others, not adhering to social dictates'. Hadas then cast self-starvation as a virtue 'more important than my life', a virtue that merited sacrifice, even death - in her words, not unlike 'dying on the altar of the homeland' (cf. Gooldin 2008). Through the sensation of hunger, then, Hadas defined and distinguished herself, setting her apart from society. Her emptiness 
equalled an exalted lightness - liminal in its presumed overcoming of the human condition; and though Hadas' words, spoken from a recovering stance, carried a sense of irony, it was notable that she positioned herself as solitary, alone in her superiority and cleanliness, in opposition to the consuming, 'contaminated' masses, inverting the sense of inferiority which she carried since childhood.

The burden of inferiority was not limited to women who were subjected to obesity stigma. Vered, who continued to struggle with anorexia after nearly a decade of illness, provided a similar account of the sensory experience of starvation as a self-defining inversion of an inferior self. Her sense of social inferiority, however, was linked to a lack of 'uniqueness', and her experience of hunger was opposite to the one described by Hadas. While Hadas spoke of desiring hunger, Vered said hunger was an object of fear:

I had moments of euphoria when I would look around and say, well, they're fat, they eat - I can not eat, like, I have some energies flowing inside me that I can't even describe - I felt very very strong.... and the admitting that you're hungry is like - I felt that I'm not clean, that I'm not pure, and that was the sensation I aspired to reach. (Vered)

Like Hadas, Vered spoke of feeling a sense of superiority over others through self-starvation. Superior selves reflected an internal redrawing of social lines; they were often rooted in social vulnerabilities - for Hadas, years of being bullied as an overweight child; for Vered, a longstanding sense of social inferiority and disdain for her positioning as a follower rather than a leader. Vered said that, as a teenager growing up in an upper-middle class suburb, she began to recognize her lack of 'uniqueness'. Having slipped from the top of the academic rankings at her school, Vered was troubled by the absence of skills and talents in which she could excel and through which she could claim her place in society. Although Israel is a collective society, with 'good citizenship' measured by institutional participation - indeed, Vered also spoke of her frustrated hopes to complete 'meaningful' IDF service - successful individuality is construed as an important part of an Israeli young adult's becoming (Maoz, 2007). Through self-starvation, however, Vered crafted an identity, marked by selfmortification, ascetic virtue (cf. O'Connor and Van Esterik, 2008) and purity (Warin, 2010) distinguishing herself from others through the liminality of transcending hunger. It was this embodied sense of identity, she said, that made her fear recovery: 'the way I saw it, it's if I'm 
separating from it (anorexia), I won't know who I am, no one else will know who I am, and no one will bother to get to know me'.

Eating disorders offered experiential extremes and a unique embodiment, redefining the self in relation to others. But superiority was only one way of conceptualizing this redefinition of selves, which extended beyond discourses of anorexic exaltation. Mirah, who recovered from bulimia after nearly two decades of eating disorders, explained that bulimic practice allowed her to enact an embodied rebellion against her perceived place in society:

In hindsight, it was something very very healthy, those binges, it was the most authentic thing I had in life. And I enjoyed them. I also enjoyed vomiting. I loved vomiting. There's something releasing like that.... I'm doing something like against nature.... It's something very forceful like that - no, childish - but there's something, a power, in that childishness. It's not that I'm accepting life with surrender.... It's something standoffish, powerful, charming. Later you have to give it up. You say, come on, I'll be boring if I won't be bulimic. I'll be like everyone else. I'll go to work, come back, kids. Such boredom. Death, death, death. Here I have action. I eat, I vomit, I have fantasies that I'll have the perfect day, I'll have the perfect life. (Mirah)

Unlike the more straightforward construction of superiority through self-starvation, binge eating conveyed an ambivalent mixture of abjection and pride, with the liminal self set on the edges of the naturally, conventionally human. For Mirah, the transgressive experience of the binge was imbued with a sense of rebellious authenticity (see also Eli, 2015). Mirah said that binge eating allowed her to reclaim the self she attempted to silence through dietary restriction - a self otherwise imbued with existential shame. Mirah's parents immigrated to Israel from North Africa and West Asia. Their immigrant experience, she said, went 'unprocessed'; the double inferiority they experienced, as Jews in Muslim countries and as Mizrahim in Israel, was transmitted through silence. Mirah began to internalize this sense of inferiority at age 12, when she was first confronted with her Ashkenazi friends' jokes about 'the Mizrahi stereotype'. Mirah linked this experience to the greater sense of shame she felt in desiring, and being forbidden, certain foods; speaking from the perspective of her adolescent self, she said: 'the boys are allowed to eat, they're my age, but it's forbidden to me, it's forbidden to take another biscuit, because I'm - I'm a girl, I'm a woman. It's shame, shame, shame.' With shame as a moving target, linked variously to her being Mizrahi, Jewish, and a woman, Mirah set on a course of dietary restriction, trying to make her 
embodied self 'clean' of fat (cf. Warin, 2010), 'like consommé'. She experienced these bouts of restriction, however, as 'being someone I'm not'. Bingeing and purging, then, emerged as a self-defining practice, providing Mirah with an embodied sense of rebelling against the social strictures that marked her as needing contraction and control.

\section{Surviving}

In August 2011, I met Hadas again; nearly six years after we first met, she said she had fully recovered from her eating disorders. Reflecting on the past, Hadas said: 'It always amazes me about eating disorders, how they simultaneously destroy your life and save your life.' She meant these words literally. As Alon, who recovered from anorexia, explained, an eating disorder was 'a quiet suicide' that satisfied the need to go through a dying process, while not facing the immediacy of death. This was not a denial of the gravity of eating disorders; Alon himself said that he sought treatment once he realized his heart rate had dropped to dangerous levels. Yet, in characterizing eating disordered practice as 'life saving' or protective, both Hadas and Alon captured the uneasy ambiguities of engaging in this potentially fatal practice. Eating disorders, as Warin (2010) argues, are characterized by ambiguities - co-existent, persistent contradictions that frame the disorder as both 'friend and foe' (p. 97), desirable and destructive. These ambiguities were central in Kinneret's narrative. For Kinneret, who had attempted suicide and continued to face persistent suicidal thoughts, eating disorder was both a compromise and a raison d'être:

There's a life you don't want to live, and there's death, and there is, in the middle, one bubble which is life, but is not life in the world where you don't want to live, and is not death. And it's in between. On the one hand, you live a little, live this life of this world, [and] on the other hand, you're going in the direction of annihilation annihilating all the, all the bad things you're sure are inside you. (Kinneret)

Kinneret began a process of recovering from anorexia, but said she still longed for her disorder. Anorexia, she said, was the only element in her life that made her feel good, determined, and motivated. It was, for a while, her place in a world where she struggled to live. Kinneret said that eating disordered practice saved her from the severe depression that led her to attempt suicide. Life, she said, was unbearable to her, and, for many years, she experienced existence as entirely meaningless and painful. Her only survival, as she 
described it, was in isolating herself - from the threats posed both by emotional connection and by belonging to mainstream society. Hospitalized repeatedly, and for extended periods of time, in closed psychiatric wards, Kinneret became a witness to extreme human suffering, densely concentrated between hospital walls. She was shaken by the pain her fellow patients had endured - the pain that brought them to the wards, and that led some of them to eventual suicide:

Inside psychiatric hospitals, you can see a lot of people who, that's what made them go crazy, sexual abuse in childhood, or rape, some kind of sexual assault, beatings within the family - [but] mostly sexual assault, mostly, and especially among anorectics, or girls who become addicted to drugs.... If your environment is also silent [about the abuse], then that's even worse. It's better to die, really. (Kinneret)

In her narrative, Kinneret linked the suffering she witnessed in the marginalized spaces of the psychiatric wards to the rules that governed mainstream, 'healthy' Israeli society and that implicitly legitimated sexual abuse: to the justice system's failure to prosecute assailants, to the military establishment's tolerance toward sexual harassment, and to the pervasive discrimination of women by these dominant institutions. Kinnert's critique was temporally situated: she spoke these words during Israel's war with Lebanon, in the summer of 2006. Kinneret reacted with pain to news about soldiers who were killed in the war, and felt doubtful about the war's righteousness. She said, however, that 'the military is [perceived as] sacred', leaving little room for public expression of doubt - and, likewise, for women to pursue justice when wronged by the system. Being and participating in this world, a world which Kinneret experienced as fundamentally violent and unjust, became an intolerable proposition which she found difficult to negotiate despite her decision to begin a recovery process. She thus continued to long for the anorexic 'bubble' she had cultivated (cf. Lavis, 2015 ) - the 'bubble' that allowed her to occupy a liminal space.

The paradoxically life-saving qualities of eating disorders came into stark view when I met with Angie. Emaciated and disabled by her eating disorder, Angie was on the brink of collapse when she said that bingeing and purging were essential to her survival.

I protected it as though - like, I didn't let anyone, like, [to] dare think about taking it away from me, because that's what, like, gives me the strength to go on and survive. Like, it's - I always used terms such as, it's my medication, it's the - like, because people, it's difficult for them to understand it, because they say, on the one hand it's 
what's killing you, [but] on the other hand you say it's your medication, so like - but yes, it's like that. (Angie)

The paradox was profound. With Angie's severe electrolyte imbalance, every purge could be fatal. Yet she spoke of bingeing and purging as an invisible shield, her protection against an oppressive world:

Like, it disconnects, it disconnects me - like, when I'm into the food, I disconnect, and also when I'm, like, after vomiting, like, I feel more, like, it's very difficult to describe it, like, it guards me somehow, like, from the world, from people, from - like, I have something of my own that protects me, and when I do it, it gives me some strength to continue surviving. (Angie)

'Surviving' was a word Angie consistently used to describe her identity and daily practice. Bingeing and purging, interspersed with days of starvation, constituted survival work: alongside self-injury, eating disordered practice was Angie's mode of cultivating a space apart from the world she feared - a world of insecurity and emotional harm, a world she actively shut out, cloistered for months in her inner city flat, emerging only sporadically at night, when she was sure of solitude and silence. Angie traced her fear of living in the world to her early childhood. Born to parents who were both addicted to heroin, Angie's illness narrative and self-definition were centred in childhood experiences of neglect and abandonment. In early adolescence, Angie developed depression and attempted suicide. A series of involuntary psychiatric hospitalizations began, and Angie left school as a result. Her hospital stays were punctuated by periods of moving from one relative's house to another, with occasional homelessness; military and national service were no longer accessible to her. Angie was off the Israeli path to 'good citizenship', her inherited social marginalization replicated and cemented through her exclusion from the institutions of secondary education and the military and her repeated subsuming into psychiatric institutions. Angie could not imagine ever negotiating the world, or the tremendous pain it made her feel. The alternative, as she saw it, was death. For Angie, eating disorder afforded a liminal 'safe space' in an unsafe world (cf. Lavis, 2015). Her ideal was to be able to determine when to have a binge not to be controlled by the urge to binge. Recovery was not an option.

\section{Conclusion}


In eating disorders, liminality is a lived state and a mode of being, an embodied drawing inward and away, at once within and without society. At its centre are embodied practice and sensory experience, which implicate the dynamics of relatedness they effect and the social suffering in which they are embedded. Clinical researchers have characterized people with eating disorders as prone to 'maladaptive' coping (Ghaderi and Scott, 2000; Troop et al., 1994) and have analysed eating disorders as providing a means of coping with dysphoria and distress through modulation of mood and state (Fairburn et al., 2003; Kaye et al., 2009). However, viewing eating disordered experiences through the lens of liminality allows us to situate these practices of coping, and their emotional antecedents, within a social, relational, and existential framework: a framework in which embodied distress is not simply relegated to the individual sufferer, but is understood as emerging from and implicating structural constraints and the difficult and sometimes oppressive bonds of social being. Rather than representing maladaptive, idiosyncratic coping mechanisms, when contextualized in the participants' greater narratives, eating disordered practices emerge as grounded in a 'logic of practice' (Bourdieu, 1990), informed by a socially-moulded being-in-the-world (Eli, 2015; Warin, 2010).

As the narratives discussed in this article illustrate, the suffering implicated in eating disorders cannot be reduced to the pain that eating disordered practices inflict in-and-of themselves. Eating disorders are serious medical conditions; however, the misery of which the participants spoke was not bound to the disorders themselves, but rather to violent and oppressive life conditions that required solutions other than psychiatric treatment. The narratives unveiled eating disorders as grounded in experiences of social suffering (Kleinman, Das, \& Lock, 1997). In some narratives, suffering could be directly linked to the socially (and clinically) recognizable experiences of abuse, neglect, and sexual trauma. In many narratives, however, social suffering was woven of the hidden threads of social exclusion, marginalization, and stigmatization: ongoing undercurrents that embed into people's daily lives, eluding the recognition afforded to "'event" assaults' (Farmer, 1996: 261). These undercurrents of social suffering, however, were not limited to the narratives of participants who were socially marginalized by socioeconomic status or ethnic background (cf. Thompson, 1992). Taken together, the narratives highlighted the 'social conditions of possibility' (Bourdieu, 1990: 26) that undergirded the participants' experiences of suffering and eating disorder. The classicism and shame that working class and socially mobile participants endured could not be separated from the measures of successful individuality and 
'good citizenship' that made middle class participants feel worthless. The political-economic structures that forced Aline to leave school and care for her disabled mother, and that perpetuated Angie's inherited legacy of poverty and neglect, were the same structures that pushed middle class women like Emily into high status military roles which they found ideologically or emotionally oppressive (see Levy and Sasson-Levy, 2008).

Most participants spoke of their suffering in individual, rather than societal, terms, their narratives revealing the 'internalization' of macro-scale structures as unquestioned aspects of the eating disordered experience (cf. Holmes, 2007: 58). Moreover, using the language of psychiatry, participants mobilized terms such as depression, anxiety, addiction, and obsessive compulsive disorder to capture aspects of their life histories and embodied experiences. This pattern reflected the extent to which psychiatric diagnoses and experiences of patienthood shape eating disordered identities (Eli, 2014a), alongside narrative structures and vocabularies (Shohet, 2007). As Kleinman (1995) argues, in the absence of collective narratives that articulate structural vulnerability at the population level, biomedically-defined conditions become a means of simultaneously expressing and occluding structurally conditioned distress. It is through disentangling these individual illness narratives from the biomedical idioms in which they are told that we can begin to discern how structural forces materialize in suffering bodies (Kleinman and Kleinman, 1994).

The clinical literature recognizes that eating disorders emerge from the interaction of individual biology and the social environment. However, extant conceptualizations of individual-environmental interaction in eating disorders entail readings of environmental influence as located in triggering media images and body ideals, with causative primacy attributed to biological predispositions (e.g., Bulik, 2012). Accordingly, in Israel, primary prevention efforts have centred on self-esteem and 'media literacy' education (e.g., Golan et al., 2014), alongside legislative initiatives targeting advertising and the fashion modelling industry (Knesset, 2012). Although such efforts rightfully recognize that media discourses propagate ideas of thinness as a desirable marker of 'success', they also risk reducing environmental influence to its symptomatic media manifestations, while overlooking the profound social suffering that people with eating disorders endure - suffering that persists independently of the thin ideal and media messages.

To understand environmental influence in eating disorders, we must consider the social suffering that underpins these disorders. Eating disorders develop within complex 
ecologies of individual, familial, social, and structural elements - ecologies that implicate sensory and physiological dispositions and processes. As a medical anthropologist, I do not deny the biological realities of eating disorders. However, I argue that, as an ethical imperative, we need to account for the central role that social suffering plays in the embodiment of these biological realities. I therefore urge researchers and practitioners, across the social and clinical sciences, to turn a critical lens toward the structural conditions that create social suffering and thereby shape eating disorders. 


\section{Declaration of conflicting interests}

The author has no potential conflicts of interest to declare with respect to the research and the authorship and/or publication of the article.

\section{Funding}

The second (2011) phase of the study upon which this article is based was funded by the Oxford University Press John Fell Research Fund.

\section{References}

Berkovitch, N. (1997). Motherhood as a national mission: the construction of womanhood in the legal discourse in Israel. Women's Studies International Forum, 20(5), 605-619.

Bourdieu, P. 1990. The logic of practice. Stanford: Stanford University Press.

Bulik, C. M. (2012). The woman in the mirror: How to stop confusing what you look like with who you are. London: Bloomsbury.

Bury, M. (1982). Chronic illness as biographical disruption. Sociology of Health \& Illness, 4(2), 167-182.

Charmaz, K. (1983). Loss of self: a fundamental form of suffering in the chronically ill. Sociology of Health \& Illness, 5(2), 168-195.

Csordas, T. J. (1993). Somatic modes of attention. Cultural Anthropology, 8(2), 135-156.

Desjarlais, R., \& Throop, J. C. (2011). Phenomenological approaches in anthropology. Annual Review of Anthropology, 40, 87-102.

Eli, K. (2014a). An embodied belonging: amenorrhea and anorexic subjectivities. Medicine Anthropology Theory, 1(1), 53-80.

Eli, K. (2014b). Between difference and belonging: configuring self and others in inpatient treatment for eating disorders. PLOS ONE, 9(9), e105452.

Eli, K. (2014c). Eating disorders during compulsory service in the Israeli Defense Forces. Military Behavioral Health, 2(1), 89-97.

Eli, K. (2015). Binge eating as a meaningful experience in bulimia nervosa and anorexia nervosa: a qualitative analysis. Journal of Mental Health, 24(6), 363-368.

Eli, K. (2016). 'The body remembers': narrating embodied reconciliations of eating disorder and recovery. Anthropology \& Medicine, 23(1), 71-85. 
Fairburn, C. G., Cooper, Z., \& Shafran, R. (2003). Cognitive behaviour therapy for eating disorders: a "transdiagnostic" theory and treatment. Behaviour Research and Therapy, 41(5), 509-528.

Farmer, P. (1996). On suffering and structural violence: a view from below. Daedalus, 125(1), 261-283.

Frank, A. W. (1995). The wounded storyteller: Body, illness, and ethics. London: University of Chicago Press.

Garrett, C. (1998). Beyond anorexia: Narrative, spirituality and recovery. Cambridge: Cambridge University Press.

Ghaderi, A., \& Scott, B. (2000). Coping in dieting and eating disorders: a population-based study. The Journal of Nervous and Mental Disease, 188(5), 273-279.

Golan, M., Hagay, N., \& Tamir, S. (2014). Gender related differences in response to "In Favor of Myself" wellness program to enhance positive self $\&$ body image among adolescents. PLOS ONE, 9(3), e91778.

Gooldin, S. (2008). Being anorexic. Medical Anthropology Quarterly, 22(3), 274-296.

Green, L. (1998). Lived lives and social suffering: problems and concerns in medical anthropology. Medical Anthropology Quarterly, 12(1), 3-7.

Holmes, S. M. (2007). "Oaxacans like to work bent over": the naturalization of social suffering among berry farm workers. International Migration, 45(3), 39-68.

Jackson, J. E. (2005). Stigma, liminality, and chronic pain: mind-body borderlands. American Ethnologist, 32(3), 332-353.

Kaye, W. H., Fudge, J. L., \& Paulus, M. (2009). New insights into symptoms and neurocircuit function of anorexia nervosa. Nature Reviews Neuroscience, 10(8), 573-584.

Kleinman, A. (1995). Pitch, picture, power: the globalization of local suffering and the transformation of social experience. Ethnos, 60(3-4), 181-191.

Kleinman, A. (2010). Four social theories for global health. The Lancet, 375(9725), 15181519.

Kleinman, A., Das, V., \& Lock, M. (1997). Introduction, in Social suffering, A. Kleinman, V. Das, and M. Lock, eds. London: University of California Press.

Kleinman, A., \& Kleinman, J. (1994). How bodies remember: social memory and bodily experience of criticism, resistance, and delegitimation following China's Cultural Revolution. New Literary History, 25(3): 707-723.

Kleinman, A., \& Kleinman, J. (1996). The appeal of experience; the dismay of images: cultural appropriations of suffering in our times. Daedalus, 125(1), 1-23. 
Knesset. (2012). The bill for weight limiting in the modelling industry, $5662-2012$. <http://fs.knesset.gov.il//18/law/18_lsr_301140.pdf> Accessed 4 August 2015.

Lasègue, C. (1873). On hysterical anorexia. Medical Times and Gazette, 2(6), 27.

Lavis, A. (2011). The boundaries of a good anorexic: Exploring pro-anorexia on the internet and in the clinic (Doctoral dissertation, Goldsmiths).

Lavis, A. (2013). The substance of absence: exploring eating and anorexia, in Why we eat, how we eat: Contemporary encounters between foods and bodies, E-J. Abbots and A. Lavis, eds. Farnham: Ashgate, 35-52.

Lavis, A. (2015). Careful starving: reflections on (not) eating, caring and anorexia, in Careful eating: Bodies, food and Care, E-J. Abbots, A. Lavis and L. Attala, eds. Farnham: Ashgate, 91-108.

Leder, D. (1990). The absent body. London: University of Chicago Press.

Lester, R. J. (1995). Embodied voices: women's food asceticism and the negotiation of identity. Ethos, 23(2), 187-222.

Lester, R. J. (2007). Critical therapeutics: cultural politics and clinical reality in two eating disorder treatment centers. Medical Anthropology Quarterly, 21(4), 369-387.

Levy, G., \& Sasson-Levy, O. (2008). Militarized socialization, military service, and class reproduction: the experiences of Israeli soldiers. Sociological Perspectives, 51(2), 349-374.

Maoz, D. (2007). Backpackers' motivations: the role of culture and nationality. Annals of Tourism Research, 34(1), 122-140.

Motzafi-Haller, P. (2012). In the cement boxes: Mizrahi women in the Israeli periphery. Jerusalem: Magnes Press.

Moulding, N. (2015). "It wasn't about being slim": understanding eating disorders in the context of abuse. Violence Against Women, 21(12), 1456-1480.

Murphy, R. F., Scheer, J., Murphy, Y., \& Mack, R. (1988). Physical disability and social liminality: a study in the rituals of adversity. Social Science \& Medicine, 26(2), 235-242.

O'Connor, R. A., \& Van Esterik, P. (2008). De-medicalizing anorexia: a new cultural brokering. Anthropology Today, 24(5), 6-9.

Quesada, J., Hart, L. K., \& Bourgois, P. (2011). Structural vulnerability and health: Latino migrant laborers in the United States. Medical Anthropology, 30(4), 339-362.

Sasson-Levy, O. (2003). Feminism and military gender practices: Israeli women soldiers in "masculine" roles. Sociological Inquiry, 73(3), 440-465. 
Shohet, M. (2007). Narrating anorexia: "full" and "struggling" genres of recovery. Ethos, 35(3), 344-382.

Thompson, B. W. (1992). "A way outa no way": eating problems among African-American, Latina, and White women. Gender \& Society, 6(4), 546-561.

Troop, N. A., Holbrey, A., Trowler, R., \& Treasure, J. L. (1994). Ways of coping in women with eating disorders. The Journal of Nervous and Mental Disease, 182(10), 535-540.

Turner, V. W. (1967). The forest of symbols: Aspects of Ndembu ritual. Ithaca: Cornell University Press.

Warin, M. (2003). Miasmatic calories and saturating fats: fear of contamination in anorexia. Culture, Medicine and Psychiatry, 27(1), 77-93.

Warin, M. (2010). Abject relations: Everyday worlds of anorexia. London: Rutgers University Press.

Karin Eli is a medical anthropologist based at the University of Oxford's Institute of Social and Cultural Anthropology. Her main ethnographic research has explored eating disorders in Israel from a longitudinal, narrative perspective, and her published work has examined identity, embodied experience, sociality, and cultural logics as they inform and maintain eating disordered practice over time. In addition to her research on eating disorders, Karin has conducted extensive collaborative research concerning childhood obesity in the US and Sweden, with particular emphasis on parental and grandparental attitudes to young children's feeding and body weight, as embedded in familial roles and structural barriers. Her most recent research has focused on assessing links between multi-generational social class, social mobility, wellbeing, and obesity among British adults. 